Annals of Warsaw University of Life Sciences - SGGW

Land Reclamation No 38, 2007: 49-56

(Ann. Warsaw Univ. of Life Sci. - SGGW, Land Reclam. 38, 2007)

\title{
Monitoring of the groundwater environment within a landfill site
}

\author{
HANNA ZŁOTOSZEWSKA-NIEDZIAŁEK \\ Department of Geotechnical Engineering \\ Warsaw University of Life Sciences - SGGW
}

\begin{abstract}
Monitoring of the groundwater environment within a landfill site. The paper presents the hydrogeological conditions and results of monitoring carried out within the "Otwock-Świerk" municipal landfill site. The object is located within the Garwolin Plain - a denuded moraine plateau composed of deposits representing Middle-Polish Glaciations. Wastes are isolated from the surrounding soil-water environment by a 1-ply complex mineral-synthetic diaphragm. The periodical increase of chlorides, total organic carbon (TOC), polycyclic aromatic hydrocarbons (PAH) and nitrites indicate the presence of pollutants of anthropogenic origin.
\end{abstract}

Key words: environment monitoring, landfill site, hydrogeological conditions

\section{INTRODUCTION}

The risk posed on the soil-water environment by a surface source of pollutants (e.g. municipal landfill site) may cause negative effects on a variable scale: from local and short-termed consequences of low nuisance, to longterm effects, lasting for many years and covering large areas. The information on the scale of this phenomenon is supplied by monitoring studies that systematically measure the parameters characterizing the environment around engineering objects: planned, exploited and in the post-exploitation phase (StaniewiczDubois ,1995; Szyszkowski 2000).
Rationally planned and conducted monitoring of the geological environment should include ground- and surfacewater, soils and grounds, as well as geodynamic processes, and accordingly should by synchronized with atmo- and hydrosphere monitoring (DzU no 220, pos. 1858, 2002).

In the case of municipal landfill sites, monitoring of environment pollution is typically restricted to the analysis of the quality of ground- and surface-water as well as leachates and sludge gas from the landfill site, whereas monitoring of the lithosphere (soils) is not sufficient enough and practically restricted to the soil horizon. Monitoring of landfill stability and basement deformations includes only control of the subsidence of the landfill surface. Active geodynamic processes, which can take place within the basement and in the stored material (i.e. deformability of basement and its susceptibility to squeezing out, basement deformation and subsidence and stability of scarps) are typically not included in the monitoring, although these elements are particularly important, because uneven basement subsidence at a large thickness (exceeding $10 \mathrm{~m}$ ) of the collected wastes can cause damage in the sealing of the site (Wysokiński, 1997; Drągowski, 2002). 


\section{MATERIAL AND METHODS}

Monitoring of the groundwater environment is presented below based on the observations carried out in the vicinity of the "Otwock-Świerk" municipal landfill site.

The object is located ca $5 \mathrm{~km}$ to the east of Otwock (Mazovian Voivodship) on swampy wastelands (Fig. 1). From the east and north the site is surrounded by forests and from the south and west by arable land. The landfill site is situated in a $1.5 \mathrm{~m}$-deep basin and rises above the surface; the landfill height is ca $24 \mathrm{~m}$ above surface level and the sides slope at $1: 1.5$. The surface of the entire object is in the range of $20 \mathrm{ha}$, of which the wastes cover 12 ha and are sub-divided into 4 quarters. The exploitation of the first quarter has terminated; at present reclamation works are conducted there.
Installation works are also carried out for the sludge gas recovery. The wastes are isolated from the bedrock by a 1-ply complex mineral-synthetic diaphragm. The object was opened in April 1998, and its exploitation should last for 30 years.

The project included collecting and analysis of the physical and chemical properties of groundwater collected from piezometers located in direct vicinity of the landfill, properties of leachates, as well as data on the subsidence of the surface of the "Otwock-Świerk" landfill site. At present, installation works are also carried out for the sludge gas recovery.

Monitoring of the quality of groundwater began in March 1999 in four piezometers (P1-P4), in mid-2003 a fifth piezometer (P5) was installed (Fig. 1).

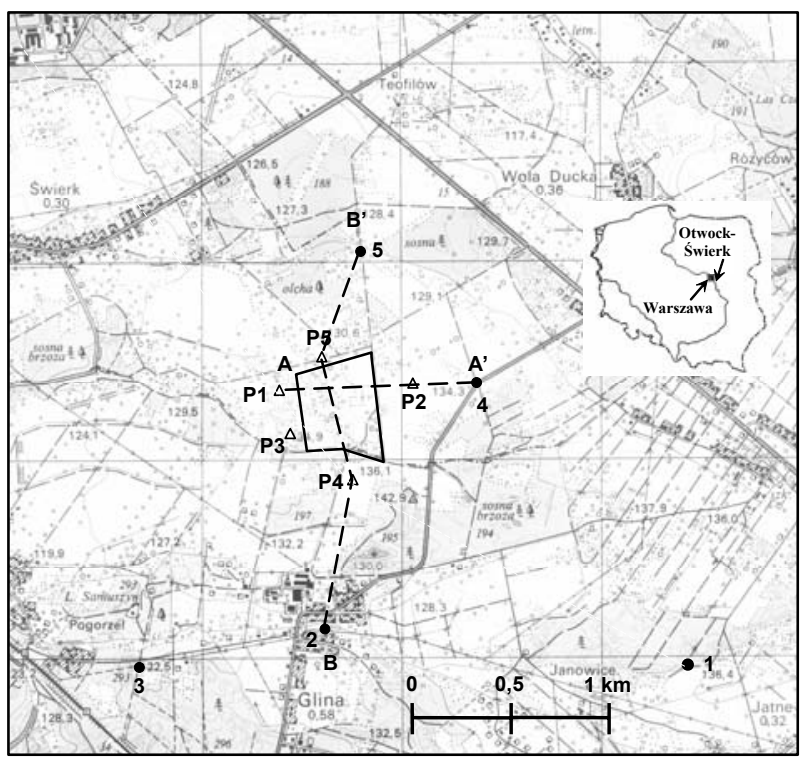

FIGURE 1. Location of the test points in the vicinity of the "Otwock-Świerk" landfill site

Explanations: - archiwal drilling, $\Delta$ piezometer, A A' line hydrogeological cross-section, landfill site 
The observation network includes points (P1-P4) characterizing the first aquifer layer, which locally occurs as interbeddings in poorly permeable deposits at the depth of 1.5-2 $\mathrm{m}$. One piezometer (P-5) tests groundwater with a free water table. The points of the monitoring network were sampled at a variable frequency and with diverse determinations. Between 1999 and 2002 water samples were collected every three months, in 2003 once a month, and since 2004 the samples are again collected every three months. The range of determinations till 2002 included: $\mathrm{pH}$, nitrites, nitrates, ammonium nitrogen, phosphates, chlorides, iron, manganese, cyanides, cadmium, lead, arsenic, and mercury. Since 2003, the determinations include also: polycyclic aromatic hydrocarbons (PAH), chemical oxygen demand (COD), total organic carbon (TOC), soluble oxygen content, electrolytic conductivity, copper, zinc, chromium; determinations of arsenic, cyanides, iron and manganese are not made.

\section{CHARACTERISTICS OF THE STUDY AREA}

The study area is located within the south-eastern margin of the Warsaw Basin on the Garwolin Plain, composed of deposits representing the MiddlePolish Glaciations (Baraniecka, 1973). The surface of the plain is denuded, and near the landfill site is located at 130-135 $\mathrm{m}$ above sea level. The study area was drained by small streams and melioration ditches flowing to the Świder and Vistula rivers.
The hydrogeological conditions in the study area are rather complicated due to the complex geological setting linked with the Wólka Mlądzka structural high. Three parallel NW-SE elevations have been distinguished in this structure. One of them, the Świerk-Wola Ducka elevation, lies at ca. $800 \mathrm{~m}$ to the north of the landfill. In this elevation the top of the Pliocene is located at $120-130 \mathrm{~m}$ above sea level, and between the elevations - at 52-60 $\mathrm{m}$ above sea level (e.g. in Glina - borehole no 2). Glaciotectonic highs within plateaux and in valley margins often act as vertical, almost non-permeable barriers (Aber, Ber, 2007). They protect the valley or deeper groundwater reservoirs against polluted groundwater from the plateau. In the study area within a disturbed complex of glacial tills, loams and clays occur lenses and interbeddings of aquifers with low hydrogeological parameters (Malinowski, 1991).

The thickness of Quaternary deposits in the area varies between $0 \mathrm{~m}$ in the Wólka Mlądzka structural high to ca 100 $\mathrm{m}$. The sub-surface deposits comprise here permeable beds developed as 1 to $4 \mathrm{~m}$ thick, medium - to fine-grained and slightly clayey sands. The presence of groundwater is linked here usually with deposits filling older paths of surface runoff within the post-glacial plateau. The groundwater table is free and its position depends on the infiltration of precipitation. This groundwater is exploited only locally due to low quantities and poor quality.

Below lies a continuous complex of 5 to $70 \mathrm{~m}$-thick, poorly permeable deposits, comprising silts, clayey sands and silts, and clays with pebbles. These deposits 
contain aquifer layers composed of 3 to $7 \times 10^{-5} \mathrm{~m} / \mathrm{s}$, discharge of the particular $\mathrm{m}$-thick, fine- to medium-grained sands exploitation wells varies between 18-24 and gravels (Fig. 2, 3). The infiltration $\mathrm{m}^{3} / \mathrm{h}$, specific discharges vary between coefficient of the aquifers is $\mathrm{k}=2.1-8.6 \times \quad 0.38-3 \mathrm{~m}^{3} / \mathrm{h} / \mathrm{m}$ (archival date of the PIG).

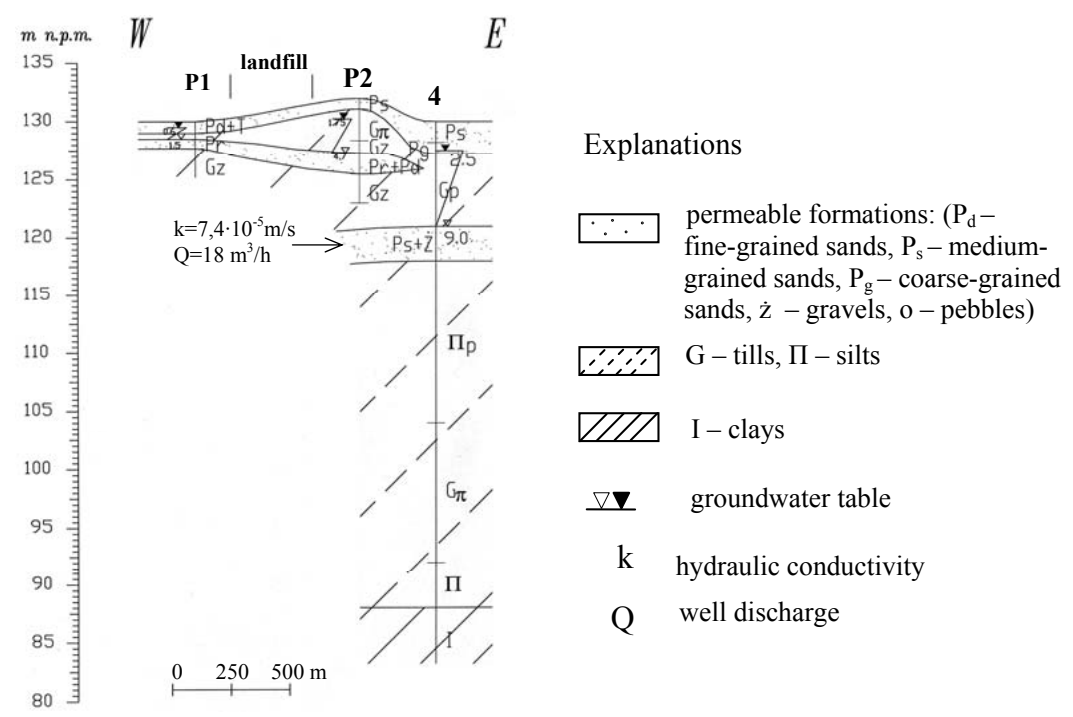

FIGURE 2. Hydrogeological cross-section A-A' through the plateau in the vicinity of the Otwock-Świerk landfill site

$$
\text { S }
$$

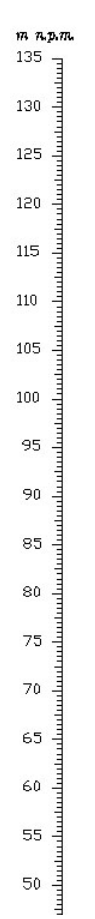

landfill

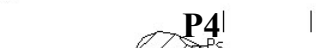

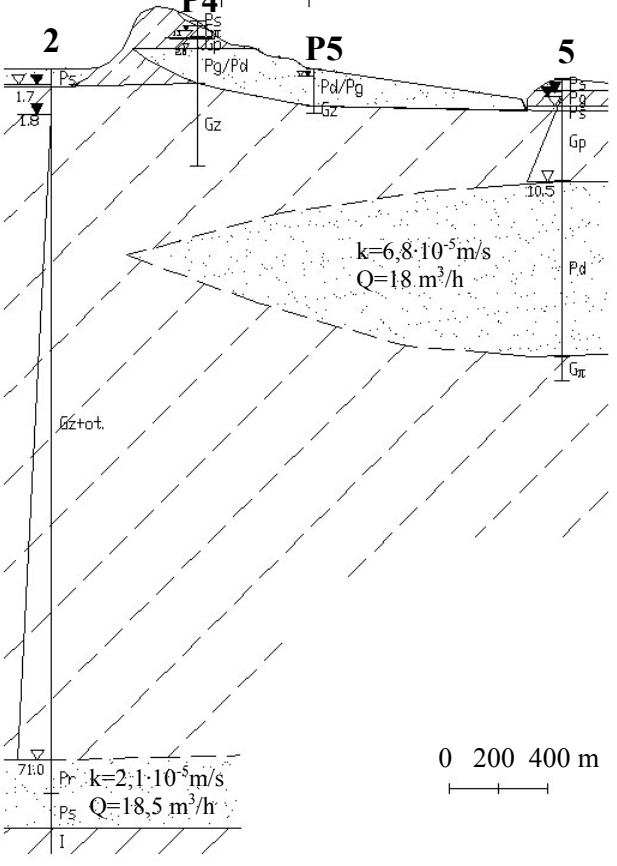

FIGURE 3. Hydrogeological crosssection B-B' through the plateau in the vicinity of the "Otwock-Świerk" landfill site (explanation as in FIGURE 2) 
Due to low hydrogeological parameters the area in the vicinity of the landfill is unfavourable in terms of water supply.

In the bedrock of the landfill, composed of glacial till, at 1.5 to $5.2 \mathrm{~m}$ below surface level occur waterlogged, 0.8 to $3 \mathrm{~m}$ thick sand interbeddings. The aquifer is composed of coarse- and fine-grained sands. The confined water table was located at $0.83(\mathrm{P} 1)$ to $4.82 \mathrm{~m}$ (P3) in the study period (October 2004 - December 2006). The amplitude of its position was between $0.71(\mathrm{P} 1)$ to 1.52 (P3). Groundwater flow within this aquifer layer is towards the north-west.

Quaternary deposits are underlain by Pliocene sediments, comprising motley clays with lenses and beds of sands. The thickness of this complex is variable, averagely several tens of meters; in the vicinity of Świerk it is evaluated at 150 m (Baraniecka, 1973). In its topmost part the Pliocene sediments are mingled with older Quaternary deposits. The surface of
Tertiary deposits in the study area occurs at 55 to $105 \mathrm{~m}$ above sea level.

\section{RESULTS OF MONITORING STUDIES GROUNDWATER QUALITY}

Based on archival data, an evaluation was made to test the changes of groundwater quality caused by a potential pollution source - the municipal landfill site. For comparison were used analyses of physical-chemical properties of water collected in 1997 from piezometers P1P4 located in direct vicinity of the landfill (Fig. 1); the analyses referred to the interval directly before exploitation. The values of physical-chemical parameters of groundwater (1997) from the first aquifer layer are given in Table 1.

Archival data show that in samples of water collected from piezometers P1-P4 in November 1997, high concentrations

TABLE 1. Values of physical-chemical parameters of groundwater (1997) from the first aquifer layer in the vicinity of the "Otwock-Świerk" municipal landfill site

\begin{tabular}{|l|c|c|c|c|c|c|}
\hline \multirow{2}{*}{ Index } & \multirow{2}{*}{ Unit } & \multicolumn{4}{|c|}{ Value } & Threshold limit \\
value *
\end{tabular}

*DzU no 35, pos. 205, 1990. 
of the physical-chemical indicators occurred at 0.9 to $3.5 \mathrm{~m}$ - Table 1 .

Table 2 shows the content of selected parameters of the chemical composition of water in the 1999-2006 interval (Monitoring of municipal landfill site Sater Otwock). Analysing the results of studies on the groundwater quality with regard to its consumption valours, it was observed that the content of nitrite nitrogen is 4 to 10 -times higher that the admissible values. In three piezometers the norm related to chlorides content was also exceeded. The content of TOC, an indicator of pollution by organic matter, classifies the water within the IV and V class of quality. Norms of the content of polycyclic aromatic hydrocarbons (PAH) have also been exceeded; their high content classifies the water between the IV and V class of water quality (Ordinance of the Minister of the Natural Environment, 11.02.2004). Heavy metals (mercury, chromium, zinc, copper, lead and cadmium) occur in trace quantities, or their content lies within the normative range. The maximal values of concentrations of particular parameters have been noted in 2003 . The generally high concentration of TOC and PAH has been observed in the first three months of that year, of nitrites in the next three months, and of chlorides in the following three months. This pattern of changes in the chemical composition should be monitored. The changing distribution during maximal concentrations is interesting in terms of the mechanism of pollution and later dispersion.

High contents of nitrites, TOC and PAH points to high pollution of water by organic matter. The presence of organic matter in shallow groundwater in the vicinity of the landfill is linked with pedogenic processes taking place in an acidic bog environment (compare organoleptic properties, such as colour and turbidity from the period before exploitation). The content of nitrites above $0.01 \mathrm{mg} / 1$ in these waters, and the periodical increase of PAH and chloride content point to the presence of anthropogenic pollution (Macioszczyk, Dobrzyński, 2002).

\section{QUALITY OF LEACHATES}

Management of leachates is focused on removing them from the landfill to a retention reservoir with a volume of

TABLE 2. Values of selected parameters of the chemical composition of groundwater from the first aquifer layer between 1999-2006

\begin{tabular}{|l|c|c|c|c|c|c|c|c|c|c|}
\hline \multirow{2}{*}{$\begin{array}{l}\text { Index } \\
{\left[\mathrm{mg} \cdot 1^{-1}\right]}\end{array}$} & \multicolumn{2}{|c|}{ P 1 } & \multicolumn{2}{c|}{ P 2 } & \multicolumn{2}{c|}{ P 3 } & \multicolumn{2}{c|}{ P 4 } & \multicolumn{2}{c|}{ P 5 } \\
\cline { 2 - 13 } & mean & $\max$ & mean & $\max$ & mean & max & mean & max & mean & max \\
\hline $\mathrm{N}-N O_{2}$ & 0.06 & 0.163 & 0.026 & 0.096 & 0.015 & 0.088 & 0.021 & 0.072 & 0.034 & 0.087 \\
\hline Chlorides & 95.45 & 588 & 33.95 & 150 & 26.78 & 160 & 23.42 & 350 & 110.98 & 370 \\
\hline $\mathrm{Mn}$ & 0.20 & 0.5 & 0.36 & 0.51 & 0.18 & 0.22 & 0.04 & 0.06 & - & - \\
\hline CODCr & 33.98 & 60.1 & 19.22 & 44.8 & 19.03 & 33.1 & 14.87 & 30.6 & 25.7 & 47.9 \\
\hline TOC & 17.68 & 29.16 & 9.48 & 26.24 & 10.71 & 30.2 & 14.10 & 64.5 & 11.73 & 22.3 \\
\hline PAH* $^{*}$ & 0.01 & 0.034 & 0.012 & 0.076 & 0.01 & 0.042 & 0.009 & 0.038 & 0.005 & 0.020 \\
\hline
\end{tabular}

$*[\mu \mathrm{g}]$ 
$3000 \mathrm{~m}^{3}$, whereas their excess is transported to a pollution processing plant. Table 3 shows the values of selected parameters of the chemical composition of leachate water collected from the main basin. analyses of the groundwater quality was variable and depended on the degree of noted anthropopression.

Comparison of water chemical com-

TABLE 3. Values of selected parameters of the chemical composition of the leachates

\begin{tabular}{|l|c|c|c|c|c|c|c|c|c|}
\hline \multirow{2}{*}{$\begin{array}{l}\text { Value } \\
{\left[\mathrm{mg} \cdot 1^{-1}\right]}\end{array}$} & \multicolumn{9}{|c|}{ Index } \\
\cline { 2 - 11 } & ${\mathrm{N}-N O_{2}}$ & Chlorides & $\mathrm{COD}_{\mathrm{Cr}}$ & $\mathrm{TOC}$ & $\mathrm{Hg}$ & $\mathrm{Cr}^{+6}$ & $\mathrm{Cu}$ & $\mathrm{Pb}$ & $\mathrm{Cd}$ \\
\hline Minimum & 0.396 & 758.0 & 325.0 & 192.0 & $<0.0001$ & $<0.005$ & 0.029 & 0.01 & $<0.001$ \\
\hline Maximum & 5.217 & 1631.0 & 395.0 & 233.0 & $<0.0001$ & 0.020 & 0.048 & 0.01 & $<0.001$ \\
\hline $\begin{array}{l}\text { Threshold } \\
\text { limit }\end{array}$ & 1 & 1000 & 125 & 30 & 0.06 & 0.1 & 0.5 & 0.5 & 0.4 \\
\hline
\end{tabular}

Comparison of the quality of leachates with the highest admissible values for parameters of pollution for sewage introduced to water and ground (DzU No 137 , pos. 984,2006 ) shows that the content of heavy metals lies within the normative range, whereas the content of other parameters is exceeded. The maximal values of concentrations of particular parameters have been noted in 2003.

\section{CONCLUSIONS}

Monitoring studies conducted near the "Otwock-Swierk" municipal landfill site characterise the range and trends in changes taking place within the soil-water environment. The object is located on the Garwolin Plain, which is a denuded glacial moraine plateau composed of deposits of the Middle-Polish Glaciations.

The observation network comprises measurement points characterising the first, 0.8 to $3 \mathrm{~m}$-thick aquifer layer, which locally occurs in form of interbeddings within poorly permeable deposits at 1.5 to $5.2 \mathrm{~m}$. The frequency and range of position in 1999-2006 with analyses from the interval directly before exploitation of the landfill shows increased values of most of the chemical parameters (nitrites, chlorides, manganese).

Periodically increased values of chlorides, TOC, PAH and nitrites in 2003 are indicators of anthropogenic pollution. The generally high concentration of TOC and PAH has been observed in the first three months of that year, of nitrites in the next three months, and of chlorides in the following three months. The diverse distribution during maximal concentration is interesting in terms of the mechanism of pollution and later dispersion.

Due to complex hydrogeological conditions (related to the presence of the Wólka Mlądzka structural high), the exploited monitoring network does not allow a complete detection of the trends and directions of changes taking place in the water-soil environment. Because of the location of piezometers, it is not possible to make a reliable evaluation of the dispersion of pollution towards the north-west of the landfill (zone of water discharge from the landfill). 


\section{REFERENCES}

ABER J.S., BER A. 2007: Glaciotectonism. Developments in Quaternary Science 6. Elsevier.

BARANIECKA M.D. 1973: Szczegółowa Mapa Geologiczna Polski, arkusz Otwock z objaśnieniami. Wyd. Geologiczne Warszawa.

DRĄGOWSKI A. 2002: Geologiczne uwarunkowania optymalizacji składowisk odpadów. Przegląd Geologiczny, Tom 50 nr $10 / 2$.

MACIOSZCZYK A., DOBRZYŃSKI D. 2002. Hydrogeochemia, strefy aktywnej wymiany wód podziemnych. Wydawnictwa Geologiczne, Warszawa.

MALINOWSKI J. (red.), 1991: Budowa Geologiczna Polski, Tom VII Hydrogeologia. Wyd. Geologiczne Warszawa.

Monitoring składowiska odpadów komunalnych Sater Otwock.

Rozporządzenie Ministra Zdrowia i Opieki Społecznej z dnia 4 maja 1990 r. w sprawie warunków, jakim powinna odpowiadać woda do picia i na potrzeby gospodarskie (DzU Nr 35, poz. 205 z 1990).

Rozporządzenie Ministra Środowiska z dnia 19 grudnia 2002 r. w sprawie zakresu, czasu, sposobu oraz warunków prowadzenia monitoringu składowisk odpadów (DzU $\mathrm{Nr} 220$, poz. 1858 z dnia 19 grudnia 2002).

Rozporządzenie Ministra Środowiska z dnia 24 lipca 2006 r. w sprawie warunków, jakie należy spełnić przy wprowadzaniu ścieków do wód lub do ziemi, oraz w sprawie substancji szczególnie szkodliwych dla środowiska wodnego (DzU Nr 137, poz. 984 z dnia 24 lipca 2006).

Rozporządzenie Ministra Środowiska z dnia 11 lutego 2004 r. w sprawie klasyfikacji dla prezentowania stanu wód powierzchniowych i podziemnych, sposobu prowadzenia monitoringu oraz sposobu interpretacji wyników i prezentacji stanu tych wód. (DzU Nr 32, poz. 284 z dnia 11 lutego 2004).
STANIEWICZ-DUBOIS H. 1995: Wskazówki metodyczne dotyczące tworzenia regionalnych i lokalnych monitoringów wód podziemnych PIOŚ, Warszawa 1995.

SZYSZKOWSKI P. (ed.) 2000: Metody badania i rozpoznania wpływu na środowisko gruntowo-wodne składowisk odpadów stałych. Wyd. El-Press, Warszawa

WYSOKIŃSKI L. 1997: Aktualne problemy budowy, modernizacji i rekultywacji składowisk odpadów komunalnych. W: Budowa bezpiecznych składowisk odpadów. VII Międzynarodowa Konferencja 26-28.02.1997 Wisła

Streszczenie: Monitoring środowiska wód podziemnych $w$ rejonie składowiska odpadów. W artykule przedstawiono warunki hydrogeologiczne oraz wyniki analiz fizyko-chemicznych wody podziemnej pobranej z piezometrów zlokalizowanych w bezpośrednim sąsiedztwie składowiska „Otwock-Świerk” oraz wód odciekowych. Obiekt znajduje się na Równinie Garwolińskiej - zdenudowanej wysoczyźnie morenowej, zbudowanej z osadów zlodowacenia środkowopolskiego. Do izolacji odpadów od otaczającego środowiska gruntowo-wodnego zastosowano jednokrotną złożoną przesłonę złożoną mineralno-syntetyczną. W sieci obserwacyjnej znajdują się punkty pomiarowe charakteryzujące pierwszą warstwę wodonośna, która występuje lokalnie $\mathrm{w}$ formie przewarstwień, w utworach słabo przepuszczalnych na głębokości 1,5-5,2 m. Porównując wyniki badań chemizmu wód z lat 1999-2006 z analizami z okresu poprzedzającego eksploatację składowiska można stwierdzić, że wartości większości wskaźników chemicznych wzrosły. Okresowy wzrost zawartości chlorków, ogólnego węgla organicznego, wielopierścieniowych węglowodorów aromatycznych i azotynów jest wskaźnikiem sygnalizującym o występowaniu zanieczyszczeń pochodzenia antropogenicznego.

\section{MS. received November 2007}

\section{Author's address:}

Katedra Geoinżynierii SGGW

02-776 Warszawa, ul. Nowoursynowska 159

Poland

e-mail:hanna_zlotoszewska_niedzialek@sggw.pl 